\title{
Living by Others' Pleasure: Marston, The Dutch Courtesan, and Theatrical Profit
}

\begin{abstract}
We have known for over a century that John Marston held a share in Children of the Queen's Revels, the all-boy playing company that first performed The Dutch Courtesan in 1604, but how this knowledge affects our understanding of his plays requires further exploration. Drawing on neglected documentary sources, this essay reappraises the company's links with the Chapel Royal choir to argue that Dutch Courtesan capitalizes on the skills that most clearly connected its performers with the royal choir, even while scrutinizing the ways in which the company turned pleasurable recreation into profit.
\end{abstract}

Early in the second scene of The Dutch Courtesan, the 'witty city jester', Cocledemoy, offers a mock 'oration' in praise of the 'most pleasurable function' of the bawd, Mary Faugh. Opening by describing her 'profession or vocation' as 'most worshipful of all the twelve companies', he eventually concludes that 'only my smooth-gummed bawd lives by others' pleasure and only grows rich by others' rising' ('Fabulae argumentum' 2-3; 1.2.27, 28, 31-2, 32-3, 50-2). ${ }^{1}$ Cocledemoy's 'only' serves to distinguish the bawd from the merchant, lawyer, and physician, whose trades he has just described, but the sex-trade was not, of course, the only means through which pleasure was sold in early Jacobean London. Cocledemoy's paean to the bawd carries with it hints of another form of 'trade', much closer to home: the theatre was itself a means of 'liv[ing] through others' pleasure', that is, the enjoyment of the paying audience. Anti-theatrical writers frequently made such associations. As long ago as the early 1580s, Stephen Gosson described playhouses as 'markets of bawdry', while in 1603 Henry Crosse described the 'arguments', or plots, of plays as 'pleasing and rauishing ... made more forcible by gesture and outward action'. ${ }^{2}$ In perhaps the most explicit elision of theatre and

Lucy Munro (lucy.munro@kcl.ac.uk) is professor of Shakespeare and early modern literature at King's College London. 
brothel, a 1616 epigram by William Goddard argues 'to choose ther'es not a pinn / Whether bawdye-howse or plaie-howse you goe in'.3

Such presumed associations between playhouse and bawdyhouse bring to the fore some uncomfortable aspects of the 'labour' that brought plays to life, and the forms of economic and erotic exploitation on which it depended. In this context, the representation of labour in The Dutch Courtesan has unsurprisingly received valuable attention from earlier scholars, notably in Garrett A. Sullivan Jr's exploration of the representation of prostitutes and working women in the play. ${ }^{4}$ I adopt here a different approach, arguing that The Dutch Courtesan's interactions with ideas of labour, trade, and profit were shaped by the institutional structures that produced it: that of the all-boy playing company, the Children of the Chapel, later known as the Children of the Queen's Revels, in which Marston himself invested. ${ }^{5}$ As Tom Rutter notes in his important study of work and the early modern stage, the status of actors 'as workers or non-workers was itself vexed and problematic'. 6 Rutter focuses on adult actors as workers, noting that plays written for the children's companies around the turn of the seventeenth century 'invoke the idea of work negatively, insisting that their theatres are spaces from which workers should be absent'. 'The material that I will explore here, however, suggests that the practices and performances of the Chapel/Queen's Revels children were no less affected by anxieties about the status of acting and singing as work.

By 1604, when The Dutch Courtesan was first performed, the Queen's Revels company appears to have been a profit-making enterprise, with a set of shareholders in both its goods and the lease of the Blackfriars playhouse where it performed. ${ }^{8}$ Yet — as I will demonstrate — its links with the Chapel Royal choir, from which it took its original name, appear to have endured into the Jacobean period.' The various uses of music and singing in The Dutch Courtesan therefore provoke questions that cut across the play's dramatic fiction and its status as theatrical commodity, directing us to consider not only the financial gain that Mary Faugh makes from the musical accomplishments of titular 'Dutch courtesan', Franceschina, but also the proceeds that the company's shareholders hoped to make from the performances of all of the boy actors and musicians. They prompt us, moreover, to consider singing and acting as vocations in themselves, and the status of the boy actors as people engaged in a 'trade' that combined these skills.

The first part of this essay explores the institutional background to these questions, revisiting what we know about Marston's involvement with the company and introducing new and neglected documents that illuminate its relationship with the Chapel Royal choir. I then turn to the question of labour in The Dutch Courtesan and the broader network of allusions to vocation and trade in which its 
representation of music and singing sits, before exploring in detail the function of music and the figure of the singer in the play. Looking in detail at its entracte music, and the various forms of song that appear within it, I argue that music is a crucial means through which the company 'liv[ed] by others' pleasure'. Reading theatre-historical material through the lens of the play, and viewing the play through the lens of theatre history, help to open up some of the persistent tensions within the simultaneously aesthetic and commercial enterprise of the Children of the Queen's Revels, tensions that helped to shape The Dutch Courtesan itself.

\section{Recreation and Profit}

In 1610, an investor in the Children of the Queen's Revels, Robert Keysar, brought a suit in the Court of Requests against Richard and Cuthbert Burbage, John Heminges, and Henry Condell. ${ }^{10}$ The suit focused on the Blackfriars playhouse, which Richard Burbage had leased to Henry Evans in 1600 for a term of twenty-one years, and on claims that Evans had divided his rights in the lease and the Queen's Revels company with other investors. In his bill of complaint, Keysar claims that Evans had granted John Marston a one-sixth share in the playhouse lease plus

one full Sixt parte of and in Certaine goodes apparell for players, propertyes, playe bookes and other thinges then and still vsed by the Chilldren of the Queenes maiestyes Revells in and aboute their playes, enterludes and other exercises by them to be acted, shewed, exercised or done, in the said great Hall, or roome, or elsewhere; by good Conveyance from the said Evans and others. ${ }^{11}$

Keysar had, he claimed, in turn purchased this share from Marston. We do not know exactly when Marston first became an investor in the company, but this event occurred before November 1604 and may have taken place as early as 1603, the apparent date of The Malcontent, the first play that he wrote for the company. ${ }^{12}$ If Keysar indeed bought a share from Marston, he had probably done so before May 1606, when he negotiated with Thomas Middleton over a play and appears to have been managing the company. ${ }^{13}$

Marston appears to have become involved with the company during the extended aftermath of its involvement in a scandal surrounding the acquisition of boy actors. In December 1601, a Norfolk gentleman named Henry Clifton sued Henry Evans, Nathaniel Giles - who was master of the choristers of the Chapel Royal and a partner of Evans in the Blackfriars enterprise - James Robinson, 
and 'others' in a bill of complaint that he entered in the court of Star Chamber. ${ }^{14}$ Clifton claimed that his son, Thomas, had been abducted by Robinson and taken to the Blackfriars playhouse, where Giles, Evans, and 'other confederates' intended to 'excercize him ... in acting of partes in base playes \& enterludes to the[ir] mercinary gayne $\&$ pryvat comoditie'. ${ }^{15}$ Clifton arrived at the playhouse and demanded that his son be released; however, he claims, Giles, Robinson, and Evans 'moste arrogantlie then $\&$ there aunswered that they had aucthoritie sufficient soe to take any noble mans sonne in this Land'. ${ }^{16}$ Furthermore, he asserts, they assured him 'that his sayd sonne should be employed in that vyle $\&$ base manner of a mercynary player in that place'; they then allegedly handed Thomas 'a scrolle of paper conteyning parte of one of theire said playes or enterludes \& him the said Thomas Clifton comaunded to learne the same by harte'. ${ }^{17}$ Despite Clifton's furious protests, Thomas was kept at the Blackfriars for 'the space of about a day $\&$ a night'. ${ }^{18}$ Eventually, however, Clifton was able to call on influential friends, including Sir John Fortescue, a member of the privy council, and his son was released.

At the heart of Clifton's case was the claim that Thomas's abduction represented an abuse of a patent issued in 1597 to Nathaniel Giles as choirmaster, which enabled him entirely legitimately to 'take such and so many Children as he or his sufficient Deputie shall think meet in all Cathedrall Collegiat parishe Churches Chappells or any other place or places aswell within liberite as without within this our Realme of England whatsoever they be'. ${ }^{19}$ Clifton claims, however, that the 'confederates' abused 'the aucthorytie $\&$ truste by your highnes to him the said Nathaniell Gyles $\&$ his deputy or deputies by your highnes sayd letters patentes given $\&$ reposed' in order to set up a company of boy actors 'for their owne corrupte gayne and Lucre'. ${ }^{20} \mathrm{He}$ makes a series of further accusations: that the boys have been taken 'againste the willes of the said Childeren theire parentes tutours masters \& governours'; that they were 'childeren noe way able or fitt for singinge nor by anie the said confederates endeavoured to be taught to singe but ... abusively employed ... only in playes \& enterludes'; and that it was 'not fitt that a gentleman of his sorte should have his sonne $\&$ heire ... to be soe basely vsed'. ${ }^{21}$ Clifton does not attack the principle of the royal patent itself; he instead claims that the patent was abused. In doing so, he alleges that Evans, Giles, and Robinson asserted that 'they had aucthoritie sufficient soe to take any noble mans sonne in this Land' and declared that 'yf the Queene ... would not bear [at] them furth in that accion, she ... should gett another to execute her comission'. ${ }^{22}$ Clifton's bill of complaint thus raises a series of questions about social rank, the limits 
of royal authority as divested in a commission or letters patent, and the relative status of singing and acting as vocations.

No answer of Evans, Giles, or Robinson to Clifton's bill has been traced, and much of the procedural records of the court of Star Chamber have been lost. As a result, the impact that the scandal over the impressment of Thomas Clifton had on Evans and the other managers of the playing company has been difficult to trace. In 1612, a later partner of Evans, Edward Kirkham, professed to be amazed that Evans could continue to lay any claim to the Blackfriars when he had been 'Censured by the Right honorable Courte of Starr-Chamber for his vnorderlie carriage and behauiour in takinge vp of gentlemens Children against theire wills and to ymploy them for players, and for other misdemeanors in the said Decree Conteyned', asserting that 'all assureances made to the said Evans Concerning the said house or playes or Interludes should be vtterlye voyde and to be deliuered vpp to be Cancelled'. ${ }^{23}$ This assertion receives some support in a reference to the abduction of Thomas Clifton and the Star Chamber's judgment — which appears to have been overlooked by theatre historians - in the Reports of Sir Edward Coke. ${ }^{24}$ As Attorney General, Coke acted as advisor and prosecutor in Star Chamber; he was also a neighbour of the Cliftons in Norfolk.

Originally published in law-French in 1611, Coke's notes cite 'l' case dun Evans' as a precedent for a case involving a patent for the King's tennis courts. The comments on the Clifton case read, in full:

Issint ou un Commission est fayt a prend garsons chauntant in Cathedrall esglises \&c. ou auters lieus ou children sont instructe a chanter, pur le furnishing del Chappell le Roy, ceux generall parrols per construction del ley ount reasonable intendement, $s c$, que tiels garsons que sont educate $\&$ taught a chaunter a querer $\&$ susteiner lour viver pur ceo, ceux poent este prize pur le service le Roy, $\&$ serra bone preferment de eux a server le Roy in son chappell, mez le fils dun gentl'homme ou alcun auter que est taught a chaunter pur son ornament, delight ou recreation, \& nemy per ceo a querer son viver, ne poyt estre prise incounter son volunt, ou le consent de les parents ou amyes, $\&$ issint fuit resolve per les deux chief Justices $\&$ tout le court del Starre-chambre anno 42. Elizab. [sic] in l' case dun Evans, que avoit par colour des tiels letters patentes prise le fils d'un Clifton (un gentle homme de qualitie de Norff.) que fuyt instruct a chaunter pur son recreation, quel Evans fuit pur le dit offence grievousment punie. ${ }^{25}$ 
A late-seventeenth-century translation of the Reports presents them thus, omitting the original's comments about the 'good preferment' that choristers may find in their royal service:

where a Commission is made to take boyes singing in Cathedral Churches, \&c. or other places where children are taught to sing, for the furnishing of the Kings Chapel, these general words by construction of Law have a reasonable intendment; $s c$. that such boyes as are brought up and taught to sing to seek and get their living by it, may be taken for the Kings Chapel; but the son of a Gentleman, or any other who is taught to sing, for his ornament, delight, or recreation, and not thereby to get his living, cannot be taken against his will, or the consents of his parents or friends; and so it was resolved by the two Chief Justices, and all the Court of Star-chamber Anno 43 Eliz. [sic] in the Case of one Evans, who had by colour of such Letters Patent taken the Son of Clifton (a Gentleman in Norfolk) who was taught to sing for his recreation: which Evans for the said offence was grievously punished. ${ }^{26}$

Intriguingly, Coke's notes do not mention acting at all. Instead, the point at issue is whether high-status children who have been taught to sing but have not been brought up with the expectation that they will work as choristers can be impressed without the consent of their 'parents or friends'. In both Coke's assessment of Evans's transgression and Clifton's complaint, the question of trade or occupation is raised, but where Clifton attacks acting as a 'base trade', ${ }^{27}$ Coke opposes singing for financial reward, or to 'get [a] living', with singing for 'ornament, delight, or recreation'.

Apparently in response to Evans's punishment at the hands of the Star Chamber, the Chapel company was reorganized. On 20 April 1602 Evans and his sonin-law and business partner, Alexander Hawkins, entered into an agreement with three new investors, Edward Kirkham, William Rastall, and Thomas Kendall. ${ }^{28}$ In return for paying half of the playhouse's annual rent, Kirkham, Rastall, and Kendall were to take half of the profits, and they also seem to have bought into the goods of the company. It seems, however, that some aspects of the company's practices remained consistent. Rastall's role in the company has hitherto been obscure, but an overlooked suit brought by Evans and Hawkins against Kirkham in the court of Chancery in 1608 sheds a little light on his activities. In his answer, which is the only part of the suit that I have so far traced, Kirkham refers to 'Articles of Agreement' between Nathaniel Giles and William Rastall, stating that 'in and by the said Articles it was Agreed and Concluded that Rastoll should paye to the said Gyles in said some of Two and Twenty shillinges weekely for ffowreteene 
yeares yf the said Gyles should continewe so longe the Maister of the Children of the Chapple', and referring to Rastall as Giles's 'deputye'. ${ }^{29}$ This evidence suggests that Giles did not withdraw from the company after the Clifton case, and that he appointed Rastall in place of an earlier 'deputy' who was probably Evans himself. As deputy, Rastall would have gained the power to use the royal patent to impress boys for the choir and, potentially, the playing company.

Thus, rather than detaching the Chapel/Queen's Revels company from the Chapel Royal, as earlier scholarship has assumed, the Clifton case seems only to have resulted in the replacement of Evans with Rastall. ${ }^{30}$ The company may have continued to acquire actors through Giles's patent - albeit, perhaps, with the assent of their parents or 'friends' - for some years. They certainly continued to offer highly polished musical performances to spectators. In September 1602, some months after the Star Chamber case, a visitor to London, Frederic Gershow, described approvingly a performance at Blackfriars, commenting that 'For a whole hour before the play begins, one listens to a delightful instrumental concert ... as on the present occasion, when a boy cum voce tremula sang so charmingly to [the accompaniment of] a bass-viol that we have not heard the life of it in the whole of our journey, unless perhaps the nuns at Milan may have excelled him'. ${ }^{31}$ It may be more significant that we have realized that when Giles was issued with a new patent by James I in September 1604 it did not mention the use of choristers as actors and thus continued to provide a legal loop-hole through which boy might be recruited for the Blackfriars company. ${ }^{32}$

Only in November 1606 does this practice appear decisively to have been halted. On 7 November, Giles was issued with another patent in which the king ordered that

wee do straightlie charge and commaunde that none of the saide Choristers or Children of the Chappell so to be taken by force of this Commission shalbe vsed or imployed as Comedians or Stage players or to exercise or acte anye ... Stage playes Interludes Comedies or tragedies for that it is not fitt or decent that suche as shoulde singe the praises of god Allmightie shoulde be trayned vpp or imployed in suche lascivious and prophane exercises. ${ }^{33}$

Furthermore, a week later, on 14 November, Thomas Kendall took on an apprentice actor, Abel Cooke, and when another Blackfriars sharer, the musician Martin Peerson, sold his share to Thomas Kendall on 11 December, the sale included a stipulation that Peerson was to continue paying 'for the dyet of one which was then his boye or servaunte and one of the actors of the sayde playes or 
enterludes'. ${ }^{34}$ Peerson's 'boye' may have appeared on the Blackfriars stage before November 1606, which would mean that impressment and apprenticeship were used in tandem in the years between 1602 and 1606, but both Kendall and Peerson could also have taken on apprentices in response to the royal prohibition against choristers working as actors.

Both the documents relating to the company and its plays are suffused with a concern over the status of the boy players' activities as what is variously termed 'imployment', 'trade', 'living', 'occupation', or 'vocation' — the question of the purpose for which they are being trained. This concern chimes in intriguing ways with Hamlet's comments about the 'little eyases' in Shakespeare's play: 'What, are they children? Who maintains 'em? How are they escotted? Will they pursue the quality no longer than they can sing? Will they not say afterwards if they should grow themselves to common players - as it is most like if their means are no better - their writers do them wrong to make them exclaim against their own succession?' (2.2.343-9). ${ }^{35}$ Roslyn L. Knutson dates this passage, which appears only in the folio version of Hamlet, to the years 1606-8, citing the Queen's Revels company's performance of political and social satire, and the danger in which they appear to have placed the entire theatre industry around this time. ${ }^{36}$ In the light of the new evidence of the continued connection between the company and the Chapel Royal, and the context of Giles's new patent in 1606, Hamlet's comments may also relate to the persistent question of whether these trainee actors were, or were not, trainee singers. Giles's revised patent suggests that the line between choirboy and player had continued to be blurred in the period between 1602 and 1606, but how many of the choirboys acted, and how many of the players could sing, as yet remains unclear.

\section{The Dutch Courtesan and the Singing Boy}

The controversy over the use of the royal patent, the appointment of Rastall, and the eventual prohibition on the use of choristers as actors form a powerful backdrop against which to consider The Dutch Courtesan, one of the Blackfriars company's 'lascivious and profane exercises'. Hamlet's comments and their freshly revealed contexts give an additional charge to Cocledemoy's 'oration' in praise of the trade of the bawd, with its references to the kinds of civic and professional roles for which other boys in their teens were being prepared through apprenticeship or education. In fact, The Dutch Courtesan is deeply interested in what it variously calls trade, occupation, profession, vocation, and function. When Freevill attempts, like Cocledemoy, to defend prostitution, he declares that 'Every man 
must follow his trade and every woman her occupation' (1.1.109-10). The play puzzles over the nature and status of these forms of professional and personal activity, and the ways in which they are shaped by factors such as age, gender, social class, nation, and criminality. Cocledemoy questions the young Holofernes Reinscure about his apprenticeship and parentage (2.1.173-87), and Mulligrub in turn questions Cocledemoy, who is disguised as a Scottish barber, about his training and trade (2.3.15-31). Towards the end of the play, Tisefew exclaims at Cocledemoy, 'Go, you are a flattering knave', to which the other man replies, 'I am so. 'Tis a good, thriving trade' (5.3.153-4). The 'Fabulae argumentum' printed with the play asserts that its 'full scope' is 'The difference betwixt the love of a courtesan and a wife' (1-2) - that is, between a woman whose love is the commodity she trades in, and the wife whose love is the basis of her 'occupation'.

In the midst of these deliberations on the status of work and trade, questions about the status of the boy actors lurk most powerfully behind the uses of music and song in The Dutch Courtesan. A commodity that the company 'sold' to its spectators, and a crucial means through which it 'liv[ed] by others' pleasure', music pervades Marston's play, helping to structure its engagements with questions of trade and profit. Like Queen's Revels plays such as George Chapman's May Day (ca 1601), Marston's own Parasitaster, or The Fawn (ca 1604) and The Wonder of Women, or The Tragedy Sophonisba (1605-6), Francis Beaumont's The Knight of the Burning Pestle (ca 1607), and Middleton's Your Five Gallants (ca 1607), The Dutch Courtesan self-consciously blurs the boundaries between the play 'proper' and the act breaks, which at Blackfriars were famously filled with instrumental music. ${ }^{37}$ Act 2 begins with the entrance of Freevill, accompanied by 'Pages with torches, and Gentlemen with music' (2.1.0 sd), the appearance of the 'gentlemen' providing a retrospective source for the music that the audience have just heard. The other act breaks are preceded by calls for music from the vintner Mulligrub and his tormentor Cocledemoy. At the end of act 2, having been literally and metaphorically 'shaved' by Cocledemoy in the guise of a barber, the distraught Mulligrub cries, 'Is there any fiddlers in the house?', to which Mistress Mulligrub replies 'Yes, Master Creak's noise' (2.3.121-2). Mulligrub's response cues the musicians: 'Bid 'em play, laugh, make merry. Cast up my accounts, for I'll go hang myself presently. I will not curse, but a pox on Cocledemoy. He has polled and shaved me. He has trimmed me' (123-6). The tunes that follow presumably adhere to Mulligrub's instruction for 'merry' music, but in doing so they also pursue Cocledemoy's project of mocking the vintner.

The end of act 3, which comes after Cocledemoy has cheated the Mulligrubs of both a goblet and an expensive jowl of salmon, follows a similar pattern, but 
here Mulligrub calls not for merriment but for sad music: 'Come, let's go hear some music. I will never more say my prayers. Let's go hear some doleful music' (3.4.123-5). Here, the music aligns with Mulligrub's emotions, but the effect is nonetheless comic, especially because it replays in a different vein his call for music at the end of act 2 . At the end of act 4 , in contrast, Cocledemoy is the one who calls for music. After Mulligrub has been carried off by officers, Cocledemoy preens himself: 'Afore the Lord God, my knavery grows unparegal. 'Tis time to take a nap, until half an hour hence .... God give your worship music, content and rest!' (4.5.144-7). The entr'acte music thus both charts and intensifies Cocledemoy's hold over Mulligrub, presenting the persecution of the vintner as a multiply pleasurable product for the spectators to delight in.

Marston's calculated use of the entr'acte music and its orientation towards both pleasure and profit provides a framework in which the play's uses of song itself appear. The Dutch Courtesan presents four characters who sing: Franceschina, Freevill, Mulligrub, and Cocledemoy. Franceschina's and Freevill's songs occur in amatory or erotic contexts, and each singer performs only for a character of another gender: Franceschina sings for Freevill and Malheureux, while Freevill sings for Beatrice. Franceschina has three songs, two for which lyrics are provided within the 1605 play-text (see 1.2.125-32 and 2.2.63-9), and one in act 5, scene 1 , for which there is only a direction, 'Cantat saltatq\{ue\}, cum cithera' ('sings and dances to the cittern' $[5.1 .19 \mathrm{sd}]) .{ }^{38}$ Freevill has two songs, one in act 2 , scene 1 , for which the 1605 quarto edition provides only a direction, 'Cantat' (B3v), and one in act 5 , scene 2 , for which a lyric, 'O love, how strangely sweet', is provided. The songs may have used the same lyric and, perhaps, tune, an approach taken in two recent productions of The Dutch Courtesan, the first at York University, directed by Michael Cordner (2013), and the second at the University of Toronto, directed by Noam Lior (2019). Additional support for using the same song twice may appear in the fact that Beatrice faints when she hears the second song: she perhaps does so because she recognizes the song as well as the singer's voice.

Erotic singing is crucial to The Dutch Courtesan but it is not the only form of singing that appears in the play. As we have seen, Cocledemoy and Mulligrub both make use of music and both are presented as singers. Their songs are different from those of Franceschina and Freevill in terms of their forms and contexts, making use of ballads and tradesmen's cries, and being less dependent upon the trained voice of the professional singer. In his dialogue with Holofernes, Cocledemoy quotes from a ballad, 'Peggy's Complaint for the Death of her Willy': 
HOLOFERnes My father, forsooth, is dead.

Cocledemoy And laid in his grave. Alas, what comfort shall Peggy then have?

It seems likely that this ballad was written by Richard Tarlton to mark the death of his fellow actor William Knell in 1587.39 In singing it, Cocledemoy places himself in a line of professional clowns, and in the process he aligns the 'work' of the boy actors of the Queen's Revels company with that of the professional stage.

A later song exploits a different set of associations. In his appearance 'like a bellman' (a town-crier or night-watchman) in act 4, scene 5, Cocledemoy sings a variation on a bellman's cry:

The night grows old,

And many a cuckold

Is now - Wa, ha, ha, ho!

Maids on their backs

Dream of sweet smacks,

And warm — Wo, ho, ho, ho!

...

Maids in your night-rails,

Look well to your light (-)

Keep close your locks,

And down your smocks;

Keep a broad eye,

And a close thigh -

The rhyme word at line 81 , which is probably 'tails', is likely to have been sung on stage — adding to the song's pervasive innuendo — but is omitted in the quarto. Another version of this song also appears in Chapman's Chapel play May Day, sung by an elderly nobleman, Lorenzo, who disguises himself as the chimney sweep Snail and imitates his cries:

Maids in your smocks, set open your locks,

Downe, downe, downe:

Let Chimney sweeper in:

And he will sweepe your chimneys cleane,

Hey derry, derry, downe. ${ }^{40}$

The repetition of the song across different plays of the same company not only establishes connections between their narratives but also connects the actors who 
played the roles - if they were not played by the same boy. Both appearances of the 'Maids in your smocks' song also stage - like the ballad fragment - the commercialization of the boy singer's 'art' in the playhouse, as he is pulled further away from the divine service of the chorister or the 'recreation' of higher-status boys.

Mulligrub's song is different again. Left alone 'in the suds' by Cocledemoy (2.3.88), he initially thinks that he is talking to 'Andrew' the barber:

Dost know one Cocledemoy in town? He made me an ass last night, but I'll ass him. Art thou free, Andrew? Shave me well. I shall be one of the Common Council shortly and then, Andrew - why Andrew? Andrew! Dost leave me in the suds? (He sings.) Why, Andrew! I shall be blind with winking. Ha, Andrew! Wife! Andrew! What means this? Wife! My money! Wife!

Karen Britland translates the 1605 quarto's 'Cantat' but otherwise lets the original direction stand. In this, she takes a different approach from another editor, David Crane, who argues that the stage direction is an error for 'Clamat' ('he shouts'), which he inserts before Mulligrub's 'Ha, Andrew!', on the grounds that 'Mulligrub would hardly sing here. ${ }^{41}$ Britland notes, however, that 'In Marston's sources for this episode - Richard Edwards's Damon and Pithias and George Whetstone's Promos and Cassandra - the scene serves as a musical interlude, lending credence to the idea that Mulligrub sings. ${ }^{4} 2$ We can, in fact, easily see how Mulligrub's singing could be played: he would first ask quite amiably 'Dost leave me in the suds?', and then sing to himself to pass the time before Cocledemoy returns, gradually realizing that he has been fooled as he speaks the words, 'Why, Andrew! I shall be blind with winking. Ha, Andrew! Wife! Andrew! What means this?' (87-90). Moreover, the fact that Mulligrub is twice associated with the entr'acte music reinforces his links with music and makes the idea of his singing more plausible.

Singing thus cuts across genders and social classes in The Dutch Courtesan, and across various forms of song, such as art-song, ballad, bellman's cry, and the song of the nightingale in act 2 , scene 1 . Even the tradition of religious song in which choristers were trained makes an appearance, in the form of Mulligrub's reference to the singing of psalms at executions (3.2.10-12), a moment that may have been richly self-conscious in its original context. This reference perhaps points up the profane uses of song elsewhere in the play, and especially its use to provide erotic pleasure. Scholars of playhouse music have spent much time on Franceschina's first song, 'The Dark is My Delight', with its bawdy punchline, 'I love to sleep 
'gainst prickle, / So doth the nightingale' (1.2.131-2), and on the way in which she is presented by Freevill as a 'siren'. ${ }^{43}$ Freevill's own use of song for erotic purposes, however, has been less often taken into account. Entering with his 'Pages with torches, and Gentlemen with music' at the start of act 2, he says,

The morn is yet but young. Here, gentlemen,

This is my Beatrice' window, this the chamber

Of my betrothed dearest, whose chaste eyes,

Full of loved sweetness and clear cheerfulness,

Have gaged my soul to her enjoyings,

Shredding away all those weak under-branches

Of base affections and unfruitful heats.

Here bestow your music to my voice.

He then delivers his song, a stage direction again reading 'Cantat'. As noted above, no lyric is provided in the 1605 text, but the lyric that appears in act 5 could possibly be featured here:

O love, how strangely sweet

Are thy weak passions,

That love and joy should meet

In selfsame fashions?

Oh, who can tell

The cause why this should move?

But only this -

No reason ask of love!

If this lyric was indeed used in act 2, scene 1, its appearance there frames Freevill's preceding speech. His reference to his former love for Franceschina as 'base affections and unfruitful heats' (2.1.7) recalls Malheureux's criticism in the play's opening scene of his friend's tendency to 'grow wild in loose lasciviousness, / Given up to heat and sensual appetite' (1.1.93-4). Franceschina's song is an embodiment of this stigmatized 'lasciviousness', challenged and succeeded by Freevill's song, which he presents as the expression of his newly disciplined and sanctified love for Beatrice.

Yet, although Freevill's singing appears to be directed to different ends it exists in an uneasy relationship with Franceschina's singing. His first song in act 2, scene 1 appears between Franceschina's songs in act 1, scene 2 and act 2, scene 2, and these juxtapositions, as Britland points out, perhaps 'cal[1] the romantic intentions of Freevill's musical display into question, rendering it either naively disingenuous 
or cynically calculating. ${ }^{44}$ Freevill's song might also undercut itself in performance. Crane suggests that it hardly matters what its lyrics said, commenting that 'Whatever the words sung to the music played by the gentlemen were, they yield place in importance to the words of Freevill's speech that precedes them'. ${ }^{45} \mathrm{I}$ am not convinced, however, that the relationship between song and dramatic context is this straightforward. If Freevill indeed sings the same song twice, as I have suggested above, its lyric would seem to reinforce the chaste romance of the situation in act 2, scene 1, and Freevill's desire to put his illicit love of Franceschina behind him. In performance, however, the tune might support long, drawn out 'O's, meaning that the song would begin to hint that Freevill's attitudes towards Franceschina and Beatrice are not as different as he would like us to think.

The singing boys who play Franceschina and Freevill both inhabit a similar position within the company's structures. The dramatic fiction presents Freevill as what Coke describes in his judgment on the Clifton case as 'the son of a Gentleman, or any other who is taught to sing, for his ornament, delight, or recreation, and not thereby to get his living'. Spectators would nonetheless have been aware that this was a boy whose performances were generating profit for company's shareholders - including, it seems, Marston himself. Freevill's singing apparently delights its onstage female spectator in act 2 , scene 1 , only to unsettle her emotions in act 5, scene 2, while Franceschina's song in act 1, scene 1 both delights and disturbs Malheureux. Both songs are, moreover, part of a theatrical economy in which delight is a saleable commodity, and Marston repeatedly exploits the desire of audiences to hear the boy players sing.

I opened this essay with the figure of the bawd and have ended it with the figure of the singing boy. If the former sought to 'liv[e] by others' pleasure' the latter was no less dependent on that dynamic relationship between pleasure and profit, as the amatory and erotic singing of Freevill and Franceschina demonstrates with particular force. As I have shown, in 1604, when The Dutch Courtesan was first performed, the choirmaster and the theatrical investor appear still to have been colluding in the 'training up' and 'employment' of performers in 'lascivious and profane exercises'. The financial 'trade' of the playing company was intertwined with the processes through which the boy actors learned their own 'trade' or vocation, either as singers or stage-players. The play exploits the skills that most clearly connected its performers with the more elevated tradition of singing for the royal choir, even as it holds up for scrutiny the way in which they accrue profits and 'get their living' through what Henry Clifton called 'the base trade of a mercenary interlude player'. 


\section{Notes}

1 John Marston, The Dutch Courtesan, ed. Karen Britland (London, 2018). Unless otherwise stated, all further references to the play are to this edition.

2 Stephen Gosson, Playes Confuted in Five Actions (London, 1582; sTC: 12095), G5v; Henry Crosse, Vertues Common-wealth: or The High-way to Honour (London, 1603; sтс: 6070.5), P2v.

3 William Goddard, A Neaste of Waspes (London, 1615; sтc: 11929), F1v.

4 Garrett A. Sullivan Jr, "'All Thinges Come into Commerce”: Women, Household Labor, and the Spaces of Marston's The Dutch Courtesan', Renaissance Drama 27 (1998), 19-46, https://doi.org/10.1086/rd.27.41917326. On alternative contexts for considering women's work, prostitution, and the theatre, see Natasha Korda, 'Staging Alien Women's Work in Civic Pageants', in Working Subjects in Early Modern English Drama, ed. Michelle M. Dowd and Natasha Korda (Farnham, 2011), 53-68, https://doi.org/10.4324/9781315546384; Duncan Salkeld, 'Comedy, Realism, and History in The Dutch Courtesan', The Dutch Courtesan, http://www.dutchcourtesan. co.uk/comedy-realism-and-history-in-the-dutch-courtesan.

5 On the play's institutional contexts see also David Crane, 'Patterns of Audience Involvement in the Blackfriars Theatre in the Early Seventeenth Century: Some Moments in Marston's The Dutch Courtesan', in Plotting Early Modern London: New Essays on Jacobean City Comedy, ed. Dieter Mehl, Angela Stock, and Anne-Julia Zwierlein (Aldershot, 2004), 97-107, https://doi.org/10.4324/9781315246659.

6 Tom Rutter, Work and Play on the Shakespearean Stage (Cambridge, 2008), 27, https://doi.org/10.1017/cbo9780511481451.

7 Ibid, 119.

8 See Lucy Munro, Children of the Queen's Revels: A Jacobean Theatre Repertory (Cambridge, 2005), 27-33, https://doi.org/10.1017/cbo9780511486067; Munro, “As it was Played in the Blackfriars": Jonson, Marston, and the Business of Playmaking', English Literary Renaissance 50 (2020), 256-295, https://doi.org/10.1086/708231.

9 On the links between the choir schools and the children's companies, see Michael Shapiro, Children of the Revels: The Boy Companies of Shakespeare's Time and their Plays (New York, 1977), 5-29.

10 See Charles William Wallace, 'Shakespeare and his London Associates', Nebraska University Studies 10 (1910), 261-360 (336-60). The bill, answer, replication, and rejoinder are now catalogued as The National Archives, Kew (hereafter TNA), REQ 4/1/1; digital facsimiles of the major documents connected with this case are available on Shakespeare Documented, http://shakespearedocumented.org. 
11 Bill of complaint in Keysar v. Burbage et al., TNA, REQ 4/1/1/1; Wallace, 'Shakespeare', 340-1.

12 Martin Wiggins in association with Catherine Richardson, British Drama 15331642, A Catalogue, 9 vols (Oxford, 2012-19), 5.16. On Marston's involvement with the company see Wallace, 'Shakespeare', 78-9, 80-2, 85-8, 90-1, 93, 100; Harold Newcomb Hillebrand, The Child Actors: A Chapter in Elizabethan Stage History (Urbana, 1926), 202; Munro, Children, 28; Munro, 'As it was Played'.

13 Robert Keysar v. Thomas Middleton, Court of King's Bench, Trinity 7 Jas I (1609), KB 27/1416, m. 1056d; for a transcription see Harold Newcomb Hillebrand, 'Thomas Middleton's The Viper's Brood', Modern Language Notes 42 (1927), 35-8, https://doi.org/10.2307/2914471. Keysar also signed two bonds with Thomas Dekker in June 1606 and one with Robert Daborne in September, all of which became subjects of lawsuits. See Robert Keysar v. Thomas Dekker, King's Bench, Hilary 10 Jas I (1613), KB 27/1437, m. 997; Robert Keysar v. Robert Daborne, King's Bench, Trinity 5 Jas I (1607), KB 27/1404, m. 904d.

14 Bill of complaint in Henry Clifton v. Henry Evans et al., STAC 5/C46/39; for a transcription see Mary C. Erler, ed., Records of Early English Drama (REED): Ecclesiastical London (Toronto, 2008), 172-7. For commentaries on this suit, see Charles William Wallace, 'The Children of the Chapel at Blackfriars, 1597-1603', University Studies of the University of Nebraska 8 (1908), 103-321 (esp. 73-83); Hillebrand, Child Actors, 160-4; Edel Lamb, Performing Childhood in the Early Modern Theatre: The Children's Playing Companies (Houndmills, 2009), 45-8, https://doi. org/10.1057/9780230594739; Julie Ackroyd, Child Actors on the London Stage, Circa 1600: Their Education, Recruitment and Theatrical Success (Brighton, 2018), 1-22.

15 STAC 5/C46/39; Erler, ed., Ecclesiastical London, 175.

16 Ibid, 175-6.

17 Ibid, 176.

18 Ibid.

19 TNA, C 66/1466, mm 7d, 8d; transcribed in Erler, ed., Ecclesiastical London, 228.

20 STAC 5/C46/39; Erler, ed., Ecclesiastical London, 173.

21 Ibid, 173-5.

22 Ibid, 175-6. The word 'at' is deleted in the original.

23 Replication in Edward Kirkham v. Richard Burbage et al., Court of Chancery, 1612, C 2/JasI/K5/25. For a transcription see Frederick Gard Fleay, A Chronicle History of the London Stage, 1559-1642 (London, 1890), 248.

24 I am very grateful to Susie Attwood for alerting me to an account of the Clifton family in Francis Bloomfield's An Essay Towards a Topographical History of the County of Norfolk (London, 1769), 867, which paraphrases and cites Coke's report. The 
report is also cited in Allen D. Boyer, Sir Edward Coke and the Elizabethan Age (Stanford, 2003), 262.

25 La Huictieme Part des Reports de Sir Edward Coke Chevalier, Chiefe Justice del Common Bank (London, 1611; sTC: 5513), 45-6.

26 'Mich. 6 Jacobi, In the Common Pleas. Jehu Webbs Case', in The Reports of Sir Edward Coke Kt. Late Lord Chief-Justice of England [...] Faithfully Rendred into English (London, 1658: Wing C4944), 692.

27 STAC 5/C46/39; Erler, ed., Ecclesiastical London, 174.

28 On the 1602 agreement and its contexts, see Wallace, 'Children', 84-94; Irwin Smith, Shakespeare's Blackfriars Playhouse: Its History and its Design (New York, 1964), 186-9; Brian J. Corrigan, Playhouse Law in Shakespeare's World (Teaneck, NJ, 2004), 75-9.

29 Answer of Edward Kirkham in Henry Evans and Alexander Hawkins v. Edward Kirkham, Court of Chancery, 1608, TNA, C 2/Chas I/E31/43.

30 See Hillebrand, Child Actors, 186, 190-1; Smith, Shakespeare's Blackfriars Playhouse, 184-5; Munro, Children, 17-18.

31 Smith, Shakespeare's Blackfriars Playhouse, 551-2. For the original German text see Gottfried von Bülow, 'Diary of the Journey of Philipp Julius, Duke of StettinPomerania, Through England in the Year 1602', Transactions of the Royal Historical Society, ns, 6 vols (1892), 6.1-67 (28), https://doi.org/10.2307/3678189.

32 Commission for Nathaniel Giles, 13 September 1604, TNA, PSO 2/25; SP 38/7; for a transcription see E.K. Chambers, ed., 'Commissions for the Chapel', Malone Society Collections, 1.4-5 (1911), 357-63 (359-62).

33 Commission for Nathaniel Giles, 7 November 1606, тNA, C 66/1708, membranes 6d, 7d; for a transcription see Chambers, ed., 'Commissions', 363.

34 Thomas Kendall v. Alice Cooke, Court of King's Bench, 1607, tnA, KB 27/1405, m. 582; Answer in Edmund and Anne Kendall v. Martin Peerson, Court of Requests, January-February 1609, REQ 2/462, pt 1. See Hillebrand, Child Actors, 197-8; Mark Eccles, 'Martin Peerson and the Blackfriars', Shakespeare Survey 11 (1958), 100-7, https://doi.org/10.1017/CCOL0521064244.011.

35 Ann Thompson and Neil Taylor, eds, Hamlet: The Texts of 1603 and 1623 (London, 2006), https://doi.org/10.5040/9781408188125.00000040.

36 Roslyn L. Knutson, 'Falconer to the Little Eyases: A New Date and Commercial Agenda for the "Little Eyases" Passage in Hamlet', Shakespeare Quarterly 46 (1995), 1-31, https://doi.org/10.2307/2871152.

37 See Linda Phyllis Austern, Music in English Children's Drama of the Later Renaissance (Philadelphia, 1992), 79-81, 83-92.

38 The Dutch Courtezan (London, 1605; stc: 17475), G3r. 
39 See Katherine Duncan-Jones, 'MS Rawl. Poet. 185: Richard Tarlton and Edmund Spenser's "Pleasant Willy”, The Bodleian Library Record 20.1-2 (2007), 76-101.

40 George Chapman, May-Day. A Witty Comedie (London, 1611: stc 4980), F1r. A further variation appears in William Haughton's 1598 play for the Admiral's Men, English-men for my Money (London, 1616; sTC: 12931), G2r, in which the song is sung by a genuine bellman.

41 The Dutch Courtesan, ed. David Crane (London, 1997), 48; see Dutch Courtezan, D2v.

42 The Dutch Courtesan, ed. Britland, 159.

43 See, especially, Linda Phyllis Austern, “'Art to Enchant”: Musical Magic and its Practitioners in English Renaissance Drama', Journal of the Royal Musical Association 115 (1990), 191-206 (205-6), https://doi.org/10.1093/jrma/115.2.191; Katrine K. Wong, Music and Gender in English Renaissance Drama (London, 2013), 29-34, https://doi.org/10.4324/9780203080801.

44 The Dutch Courtesan, ed. Britland, 128.

45 Crane, 'Patterns', 106. 